\title{
Sources of urea in arctic seas: seasonal fast ice?
}

\author{
R. J. Conover ${ }^{1,2, *}$, N. Mumm ${ }^{2,{ }^{\dagger}}$, P. Bruecker ${ }^{3, * *}$, S. MacKenzie ${ }^{1, * * *}$ \\ ${ }^{1}$ Department of Biology, Dalhousie University, Halifax, Nova Scotia B3H 4J1, Canada \\ ${ }^{2}$ Department of Fisheries and Oceans, Biological Sciences Branch, Bedford Institute of Oceanography, PO Box 1006, \\ Dartmouth, Nova Scotia B2Y 4A2, Canada \\ ${ }^{3}$ Canada Department of Fisheries and Oceans, 501 University Crescent, Winnipeg, Manitoba R3T 2N6, Canada
}

\begin{abstract}
Twelve profiles for dissolved nitrogen, including nitrate, ammonia and urea, and for chlorophyll-related pigments, were taken between February 4 and November 23, 1993, as part of a seasonal study of biological oceanography of Resolute Passage, Northwest Territories, Canada. An additional 20 or 23 profiles of salinity, chlorophyll and total dissolved nitrogen obtained between January 16 and December 13,1993, from up to 10 depths provided background data in the same area. Eight short cores from seasonal fast ice in the same environment were analyzed for dissolved nitrogen species between January 30 and December 4, 1993, omitting the open water period from early to midJuly through the beginning of October. In the water column, nitrate was the predominant dissolved nitrogen source throughout most of the ice season, but it largely disappeared following break-up, as chlorophyll and its derivative pigments increased. By mid-October nitrate reappeared in the subsurface water and was the dominant nitrogen source again by late November. Ammonia and urea concentrations in the water column were relatively low and variable over the winter, declining in spring, but increasing moderately, although erratically, during June at the onset of the seasonal melt, and continuing to fluctuate through summer and fall. In the ice, ammonia and especially urea were the dominant nitrogen sources, culminating in a large, but non-uniformly distributed, standing stock of regenerated nitrogen, with urea the most concentrated, in late May near the time of maximum ice thickness. At freeze-up, regenerated nutrients, and particularly urea, appeared in the new ice, generally at concentrations greater than in the water just under the ice. We argue that a considerable amount of carbon, as part of the urea molecule, is also incorporated into the ice seasonally.
\end{abstract}

KEY WORDS: Urea - Ammonia - Nitrate - Total dissolved nitrogen - Carbon Melt B Break-up . Desalination · Freeze-up · Fast ice · Chlorophyll $\cdot$ Phaeopigments

\section{INTRODUCTION}

In the open waters of the Arctic Ocean in summer, nitrate concentrations may become virtually undetectable, but, even so, Harrison \& Platt (1986) were unable to demonstrate a statistical linkage between nutrients and phytoplankton in the eastern arctic in

\footnotetext{
Present addresses:

-7415 McAllister Road, RR2, Bewdley, Ontario KOL 1E0 Canada. E-mail: rconover@eagle.ca

" 343 East 11 th Street, North Vancouver, British Columbia V7L 2H1, Canada

-247 B Collingwood Street, Kingston, Ontario K7L 3X9, Canada

${ }^{t}$ Deceased
}

summer. Silicate may share the role of 'limiting nutrient' in northern high latitudes, where diatoms often predominate in phytoplankton communities (Rey \& Skjoldal 1987, Stefansson \& Olafsson 1990), perhaps confounding the role of nitrate. On the other hand, reduced forms of nitrogen, particularly ammonia and urea, were commonly detected in considerable abundance during the productive season and their availability may at least partially explain the lack of apparent nitrogen limitation in the absence of the usual inorganic nitrogen sources (Harrison \& Cota 1991).

What makes polar environments truly unique is the presence of ice. It caps the ocean, limiting gas and heat flux, and, together with variable amounts of snow on its surface, strongly affects light penetration. It also provides a substrate for development of plant and ani- 
mal communities, and it greatly influences the thermohaline structure of the waters immediately beneath. This environment, including the multi-year ice component, is also greatly influenced by seasonality, for its aerial extent may change by 2 to 3 times annually (Maykut 1985).

Along the edge of seasonal ice during early stages in the annual melt cycle, the melt water contributes stability favoring blooming by phytoplankton, initially as mostly 'new' (nitrate) production, and later, depending on the amount of physical mixing, some fraction as regenerative production (Legendre et al. 1992), as in virtually any open marine environment (Dugdale \& Goering 1967). However, under the ice, the environment is very different with light, first penetrating a variable thickness of snow and ice, limiting primary production by the thin, but very concentrated, layer of ice algae from above, and with physical forces, such as tidal current speed, controlling the nutrient flux to the ice algae from below (Cota et al. 1987, Cota \& Horne 1989).

In addition to the inorganic nitrogen associated with water just beneath the ice, there are additional sources directly associated with the ice that may affect the primary production process. During the processes of freezing, sea water undergoes desalination in which 60 to $70 \%$ of the salts, including the major nutrient salts, are rejected as brine, a portion of which may nonetheless be retained in brine channels within the ice and thus can be utilized as a nutrient source by developing ice algae. Analyses of inorganic nutrients, mostly 'new', within the ice cores suggests that they are distributed in approximately the same proportion as the partially rejected brine salts (Grainger 1977, Cota et al. 1987. Hsiao 1988). A third nutrient source is, of course, the regenerated nitrogen, usually considered to be mostly ammonia, which is incorporated into the ice always in higher concentrations than those found in the adjacent sea water (Hsiao 1988).

In the accompanying paper Conover \& Gustavson (1999, in this issue) have reviewed the literature concerning the distribution of the regenerated nitrogenous nutrient urea in the water column in high latitudes and have examined one possible source, excretion by zooplankton. Here we examine another possible source, seasonal fast ice.

\section{MATERIALS AND METHODS}

As part of a 12 mo study (POLAR PRO) initiated in January 1993, sampling was carried out in Resolute Passage, Northwest Territories, Canada, and nearby waters (see Fig. 1 in Conover \& Gustavson 1999). During the winter (January 16 to July 1 1993) a portable structure, equipped with a hydraulic winch, was main- tained over a hole of approximately $1 \mathrm{~m}^{2}$ at a site about $5 \mathrm{~km}$ off Sight Point in $100 \mathrm{~m}$ of water. Transportation to the site was usually accomplished with a Bombardier tracked vehicle equipped with a hydraulic power take-off to drive the sampling winch. From July 27 to September 16 sampling was carried out from a $7 \mathrm{~m}$ gasoline-powered launch, also equipped with a hydraulic winch, from a location near the site of the earlier ice station. After freeze-up in the fall, sampling was carried out initially (October 15 to 21) in Resolute Bay over $35 \mathrm{~m}$ of water and, from November 10 to December 13, from an 'ice shack' in Allen Bay over about $80 \mathrm{~m}$ depth, in each case through a hole cut in the ice with a chain saw and using a portable electric winch and generator pulled to the site with a snowmobile.

At all locations (12 dates in all) water samples for ammonia/urea and nitrate were collected, following filtration, in dedicated, acid-washed $125 \mathrm{ml}$ polyethylene bottles from 51 Niskin-bottle casts from up to 8 depths, and were kept frozen at $-20^{\circ} \mathrm{C}$ until analysis. Although it is generally considered safest to analyze ammonia samples as soon as possible after collection without further treatment, because the problem of transportation to the shore-based laboratory without freezing is difficult to overcome, we decided to standardize by freezing all samples, which were usually analyzed within a week. However on several occasions samples were held in the freezer for up to $8 \mathrm{wk}$ without showing evidence of contamination. Nitrate samples were returned to the Bedford Institute of Oceanography (BIO; Nova Scotia, Canada) for later analysis. Particulate samples were taken from the same cast for chlorophyll and CHN, after being filtered through previously baked Whatman GF/F filters, and were also frozen at $-20^{\circ} \mathrm{C}$ until analysis. A second series of water bottle collections from up to 10 depths were made on 23 dates at the same stations, but usually on different dates than for the nitrogen profiles above, to determine salinity, chlorophyll $a$ and total dissolved nitrogen (TDN).

Ice samples were usually taken by auguring to the desired depth followed by collection of several short cores with a SIPRE coring device. Cores were stored, after being immediately wrapped in polyethylene, in previously washed 81 carboys and kept frozen until melting just prior to analysis for ammonia and urea, generally within a week. Nitrate samples from the ice were also returned to BIO for analysis, but regrettably most were lost.

Samples were collected rather differently on May 25, 1993. By this date the ice shack had become deeply embedded in the ice and it was decided to move it to a new location about $100 \mathrm{~m}$ from the original site. The ice was by this late date about 1.8 to $1.9 \mathrm{~m}$ in thickness and, to cut a new sampling hole, repeated auger holes, 
in this case 9, were made close together, leaving a central core, which was hauled out of the hole with ice tongs and then sub-sampled.

Ice samples taken early in the following fall were also handled slightly differently. Because of the relative thinness of the ice, it was impractical to use a conventional SIPRE corer for this series of observations. As an alternative, we cut out ice blocks roughly $50 \times 50 \mathrm{~cm}$ by the ice thickness, here about 14 to $17 \mathrm{~cm}$, with an ice chisel and dragged them out on to the ice on their side with ice tongs. Previously we made a simple stainless steel core tube which could be hammered into the ice to take a short core (ca 5 to $6 \mathrm{~cm}$ ) from the top, bottom and side of the block. Duplicate cores were made and stored in pre-washed, wide-mouth plastic sample jars at $-20^{\circ} \mathrm{C}$ or colder until analysis.

Ammonia was determined by the Solòrzano (1969) method and urea by a slight modification of the method of McCarthy (1970) as in Harrison et al. (1985). Nitrate was determined with a Technicon II Autoanalyzer also as described in Harrison et al. (1985). TDN was also measured with the autoanalyzer following the procedure outlined in Stainton et al. (1977) after first filtering the samples through previously baked Whatman GF/C filters. Chlorophyll and pheopigments were determined by fluorescence after Yentsch \& Menzel (1963) using 90\% acetone as the solvent or, following Welch et al. (1988), using 95\% methanol to determine chlorophyll a. Some salinity-temperature curves were taken with a Guildline Model 8671 CTD Probe, but because of technical difficulties, salinity from late August through December was determined from water bottle samples using a Guildline Autosal salinometer.

\section{RESULTS}

\section{Physical environment}

From January 29 until June 11, 1993, water under the ice of Resolute Passage was nearly isothermal and isohaline to at least $30 \mathrm{~m}$, with surface salinity generally greater than $32 \%$, although there was some variability during this period (Fig. 1). Earlier observations in the Resolute area have demonstrated occasional reversals of the prevailing southeasterly currents, resulting in sudden freshening of the surface waters with input from the south side of Barrow Strait (Bedo et al. 1990). A similar phenomenon may have contributed to the variability in 1993. Clear evidence of surface melt water appeared in early July followed by breakup on July 16. Further freshening persisted until at least September 3, when a salinity minimum of $27.73 \%$ was observed from a water bottle sample. By the end of September, ice had started to form and surface salinity was over $29 \%$ and nearly isohaline over the upper $10 \mathrm{~m}$. Salination continued during the remainder of the field study, with the highest surface salinity for the new season $(31.70 \%)$ recorded on December 13,1993 , the final sampling date.

\section{POLARPRO Salinity (\%o) - 1993}

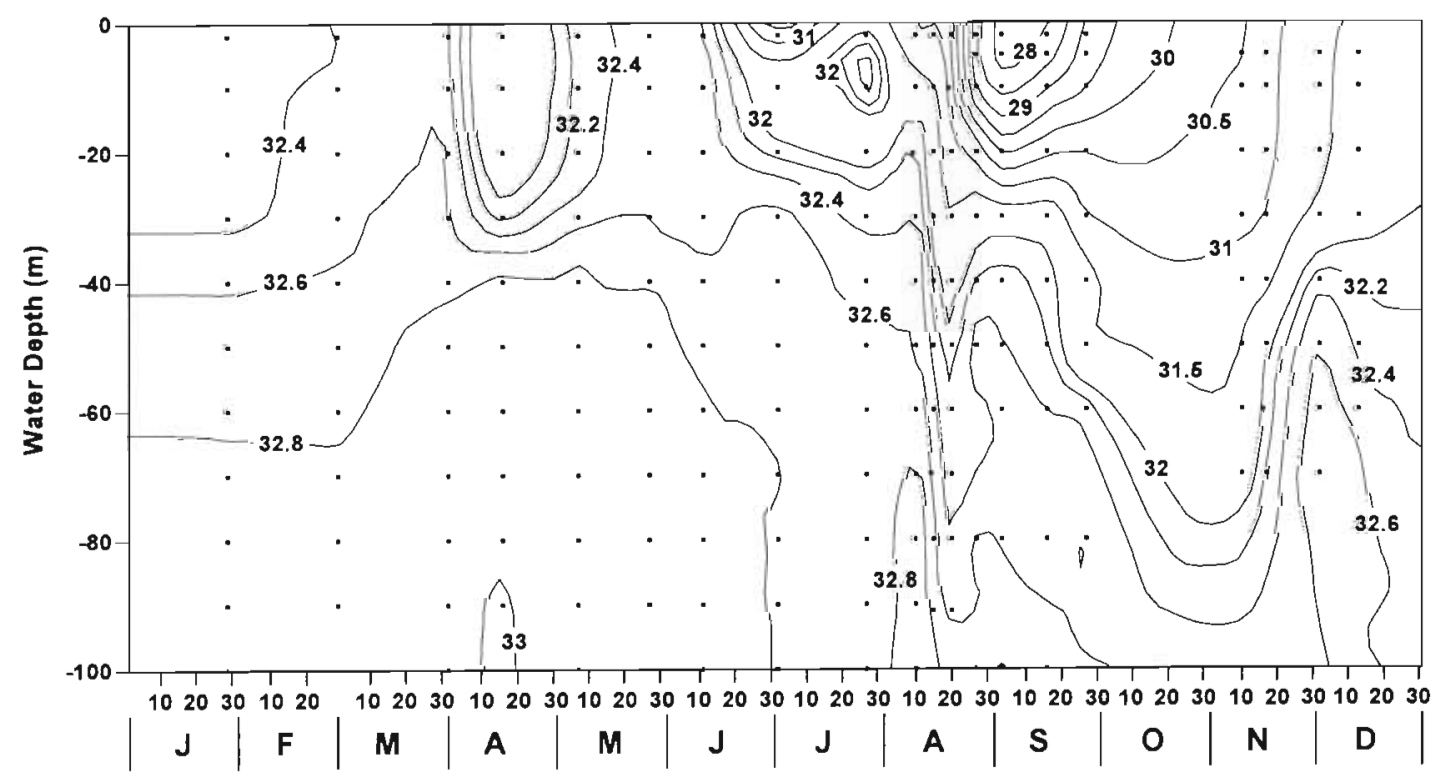

Fig. 1. Seasonal salinity distribution in 1993 in Resolute Passage, and, following freeze-up, in Allen Bay, based on Guildline CTD data through August 20, after which salinity was determined separately from water bottle samples 


\section{POLARPRO Chlorophyll ( $\mu \mathrm{g} / \mathrm{L})$ - 1993}

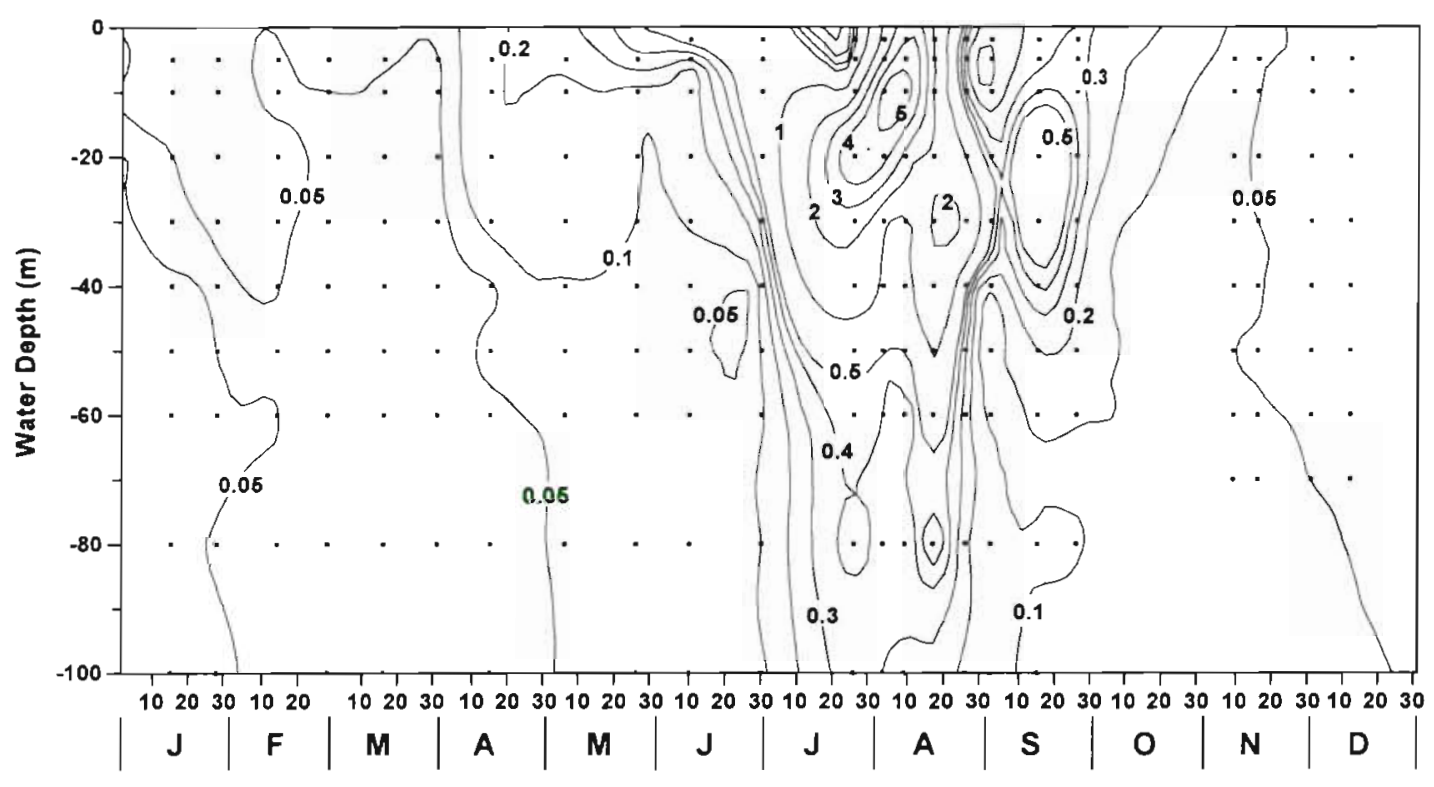

Fig. 2. Seasonal distribution of chlorophyll a in the water column in Resolute Passage and vicinity

\section{General distribution of particulate matter}

Chlorophyll and related pigments were barely detectable in the water column from freeze-up in October until April, when there was sufficient light to support primary production on the underside of the ice. A short-lived 'spring' phytoplankton bloom, based on chlorophyll a analyses, followed as the ice dissipated in July (Fig. 2) which was also accompanied by 10 -fold increases in both particulate nitrogen and particulate carbon (not shown). These manifestations of primary production were some what more persistent than the chlorophyll, but the standing crops of all the finer particulates were much reduced by freeze-up.

\section{Distribution of TDN}

During winter and spring of 1993, TDN seemed to show a rather regular oscillation with an approximately $30 \mu \mathrm{g}$-at. $\mathrm{l}^{-1}$ mode and a $30 \mathrm{~d}$ periodicity, suggesting lunar tidal influence (Fig. 3). This 'tidal' signal could be examined at several depths but it is doubtful that our sampling interval was sufficiently short to demonstrate the phenomenon statistically. Earlier observations off Resolute have shown that physical forcing in the form of tidal currents could affect nitrogen flux to the under-ice surface (Cota et al. 1987, Cota \& Horne 1989).
During open-water season, TDN, which includes both inorganic and organic material, some of which might be in the form of bacterial contamination (Paul \& Carlson 1984), fluctuated around $18 \mu \mathrm{g}$-at. $\mathrm{I}^{-1}$, with this minimum apparently persisting through the fall salination until freeze-up (Fig. 3). However, following midSeptember, it was also impossible for us to sample with small boats so there is a sampling gap of about a month until the ice would again support snowmobiles. By this time all signs of a tidal signal had disappeared.

\section{Chlorophyll - dissolved nitrogen interrelationships in the water column}

As there was very little information on the forms of nitrogen available seasonally in the high arctic, except during open-water season, we thought it might be instructive to examine the proportions of new versus regenerated nitrogen in Resolute Passage, even though we were not equipped to examine its utilization by the food web. No nitrate samples were collected on February 4, 1993, but there was evidence for some accumulation of regenerated nitrogen, mostly urea, near the bottom of the halocline (over $1 \mu \mathrm{g}$-at. $\mathrm{l}^{-1}$ at 20 and $30 \mathrm{~m}$ ), but the results were confounded by the presence of a chaetognath in the $30 \mathrm{~m}$ sample. All later samples were pre-filtered. Later in February, nitrates were relatively high and there was little regenerated nitrogen present except at $10 \mathrm{~m}$ (Table 1). By the end 
POLARPRO TDN ( $\mu \mathrm{g}$ at/L) - 1993

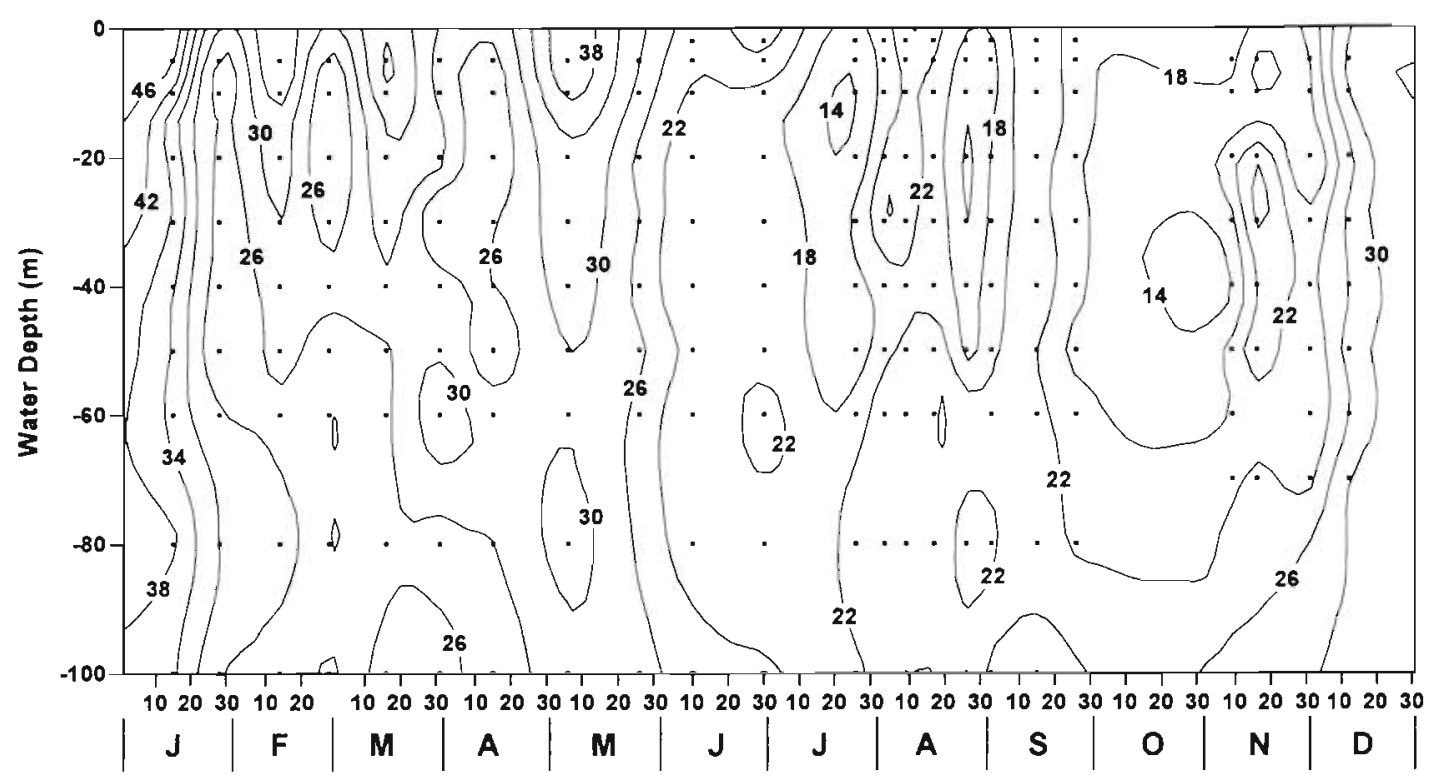

Fig. 3. Seasonal distribution of total dissolved nitrogen (TDN) in the water column in Resolute Passage and vicinity

of March, nitrate had been reduced but remained greater than $4 \mu \mathrm{g}$-at. $\mathrm{l}^{-1}$, ammonia was almost undetectable and urea was generally less than $1 \mu \mathrm{g}$-at. $\mathrm{l}^{-1}$ (Fig. 4A); there also seemed to be a small pulse of nearice phaeopigment (Fig. 4B). By mid-April there was further reduction of nitrate $\left(<2.4 \mu \mathrm{g}\right.$-at. $\left.\mathrm{l}^{-1}\right)$ in the upper $20 \mathrm{~m}$, but little regenerated nitrogen (ca $0.15 \mu \mathrm{g}$-at. $\mathrm{l}^{-1}$ ammonia and urea summed), and the chlorophyll in the water column was $<0.05 \mu \mathrm{g} \mathrm{l}^{-1}$. Ice-algal biomass during POLARPRO followed the typical exponential growth pattern initiated shortly after the first 'sunrise' in February (Welch \& Siferd unpubl.) so ice-algal production was probably on the increase at this time (Smith et al. 1988, Bergmann et al. 1991). In late May, when ice was near maximum thickness, there was further disappearance of nitrate (mean $2.4 \mu \mathrm{g}$-at. $\mathrm{l}^{-1}$ ), some ammonia (mean $0.37 \mu \mathrm{g}$-at. $\mathrm{l}^{-1}$ ) but almost no urea $\left(<0.04 \mu \mathrm{g}\right.$-at. $\left.\mathrm{l}^{-1}\right)$ in the water column; some chloropigment, possibly eroded from the ice, was present in the upper $30 \mathrm{~m}$ (mean $0.17 \mathrm{\mu g}^{-1}$ ) but it was largely in the form of chlorophyll breakdown products (chlorophyll/pheopigment ratio 0.053). In early June near surface nitrate increased slightly (mean $3.41 \mu \mathrm{g}$ at. $\mathrm{l}^{-1}$ ), with few regenerative products present (mean ammonia $0.07 \mu \mathrm{g}$-at. $\mathrm{l}^{-1}$, mean urea $0.22 \mu \mathrm{g}$-at. $\mathrm{l}^{-1}$ ), but, for the first time, chlorophyll exceeded its breakdown products (mean chlorophyll/pheopigment ratio, upper $10 \mathrm{~m}, 1.72$ ); later on in June, surface nitrates became diminished with increasing amounts of regenerated nitrogen present (Fig. 4C) but with chlorophyll still largely concentrated in the near surface water (Fig. 4D).

The conditions around ice break-up, and also around freeze-up, made sampling hazardous. In 1993, break-

Table 1. Distribution of ammonia, urea, nitrate and chloropigments with depth in samples collected between 10:00 and 10:45 h on February 24, 1993, at the sampling station off Sight Point

\begin{tabular}{|c|c|c|c|c|c|c|}
\hline $\begin{array}{l}\text { Depth } \\
\text { (m) }\end{array}$ & $\begin{array}{l}\text { Ammonia } \\
\left(\mu g \text {-at. } l^{-1}\right)\end{array}$ & $\begin{array}{c}\text { Urea } \\
\left(\mu g \text {-at. } \mathrm{l}^{-1}\right)\end{array}$ & $\begin{array}{c}\text { Nitrate } \\
\left(\mu g \text {-at. } ~^{-1}\right)\end{array}$ & $\begin{array}{c}\text { Chiorophyll } \\
\left(\mu \mathrm{g} \mathrm{l}^{-1}\right)\end{array}$ & $\begin{array}{l}\text { Pheopigments } \\
\qquad\left(\mu \mathrm{g} \mathrm{l}^{-1}\right)\end{array}$ & $\underset{\left(\mu \mathrm{g} \mathrm{l}^{-1}\right)}{\operatorname{Sum}}$ \\
\hline 1 & 0 & 0 & 8.82 & 0.01 & 0.04 & 0.05 \\
\hline 10 & 0.52 & 1.15 & 7.53 & 0.01 & 0.04 & 0.05 \\
\hline 20 & 0 & 0 & 7.64 & 0.01 & 0.04 & 0.05 \\
\hline 30 & 0 & 0 & 8.45 & 0.01 & 0.01 & 0.02 \\
\hline 50 & 0 & 0 & 9.30 & 0.01 & 0.04 & 0.05 \\
\hline 100 & 0 & 0 & 10.05 & 0.01 & 0.06 & 0.07 \\
\hline
\end{tabular}



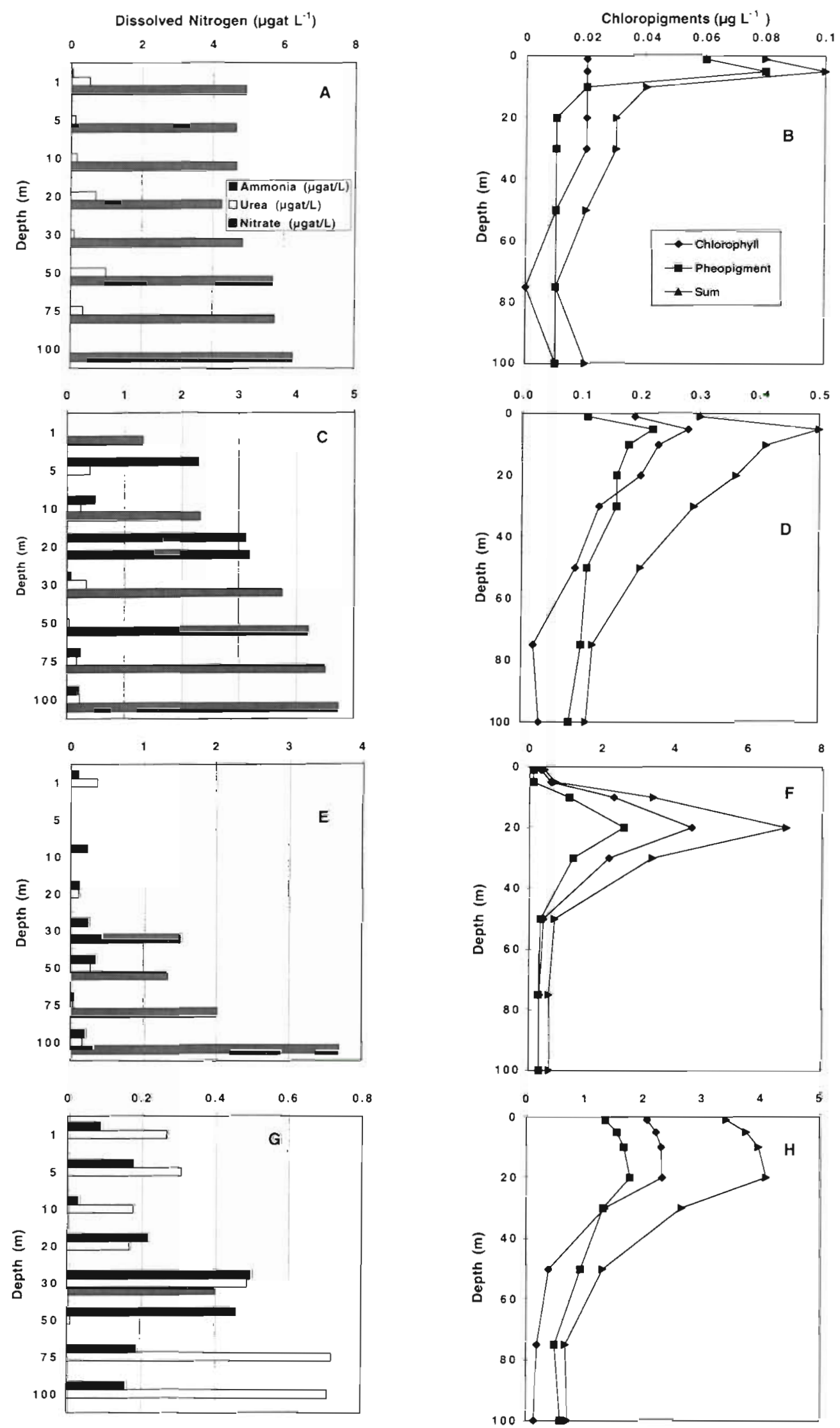

Fig. 4. Distribution of dissolved nitrogen species compared with chlorophyll-related pigments in the water column in Resolute Passage near the ice camp, spring and summer 1993. (A, B) March 29; (C, D) June 25; (E, F) July 27; (G, H) August 16 
up occurred on July 16, but, with southerly winds maintaining the loose pack along the north side of Barrow Strait, it was not until July 27 that we could reach the former ice station by boat, by which time nitrate was gone from the upper water column (Fig. 4E), regenerated nitrogen was in short supply, and the phytoplankton bloom had begun to sink, although the chlorophyll fraction still exceeded the pheopigments (Fig. 4F). In mid-August nitrate was virtually gone from the entire $100 \mathrm{~m}$ water column, although there was a modest increase in regenerated nitrogen, particularly urea (Fig. 4G), and chlorophyll-related compounds remained moderately abundant (Fig. $4 \mathrm{H}$ ).

In the fall, thin ice delayed the return to ice sampling until mid-October, and, even then, initial observations were carried out in semi-enclosed Resolute Bay, where we apparently observed considerable nitrate regeneration, along with moderate pulses of ammonia and urea (Fig. 5A), and about $0.25 \mu \mathrm{g} \mathrm{l}^{-1}$ of chlorophyll a (Fig. 5B). Resolute Bay does receive the untreated waste of the several hundred inhabitants of the village of Resolute, but, as it is theoretically diluted by a factor of $10^{3}$ by local freshwater run off (Welch et al. 1997), logically its influence would not appear to be great, especially at depth. By November 23, sampling had been extended to Allen Bay, where nitrate was now about $3 \mu \mathrm{g}$-at. $\mathrm{l}^{-1}$ at the surface and up to $10 \mu \mathrm{g}$-at. $\mathrm{l}^{-1}$ at

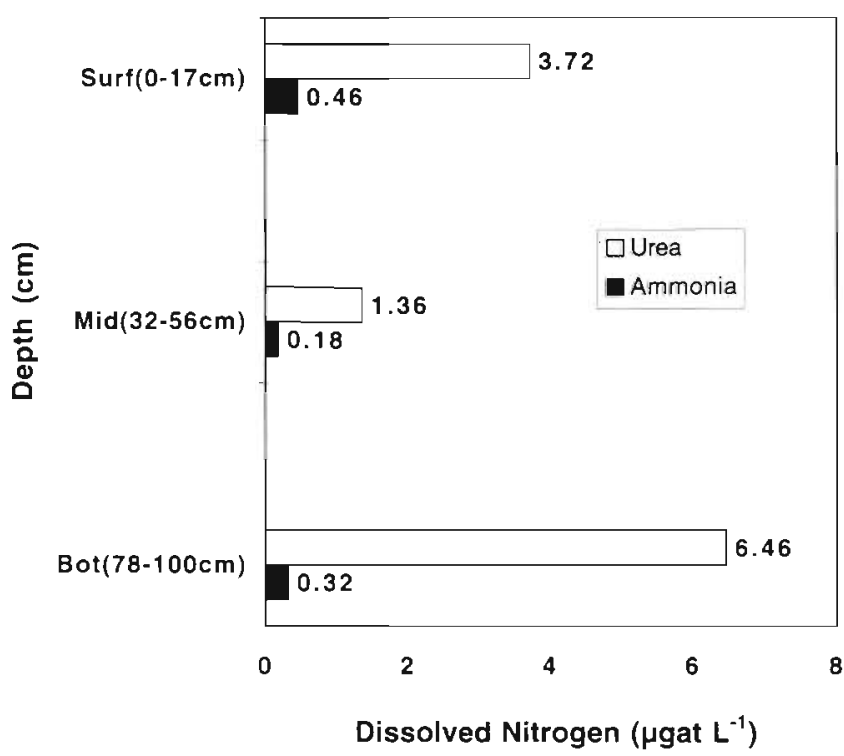

Fig. 6. Distribution of ammonia and urea in sea ice near the ice camp off Sight Point, January 30, 1993

$75 \mathrm{~m}$ (also present was a large pulse of urea of uncertain origin; Fig. 5C), and chloropigments were all but gone (Fig. 5D)
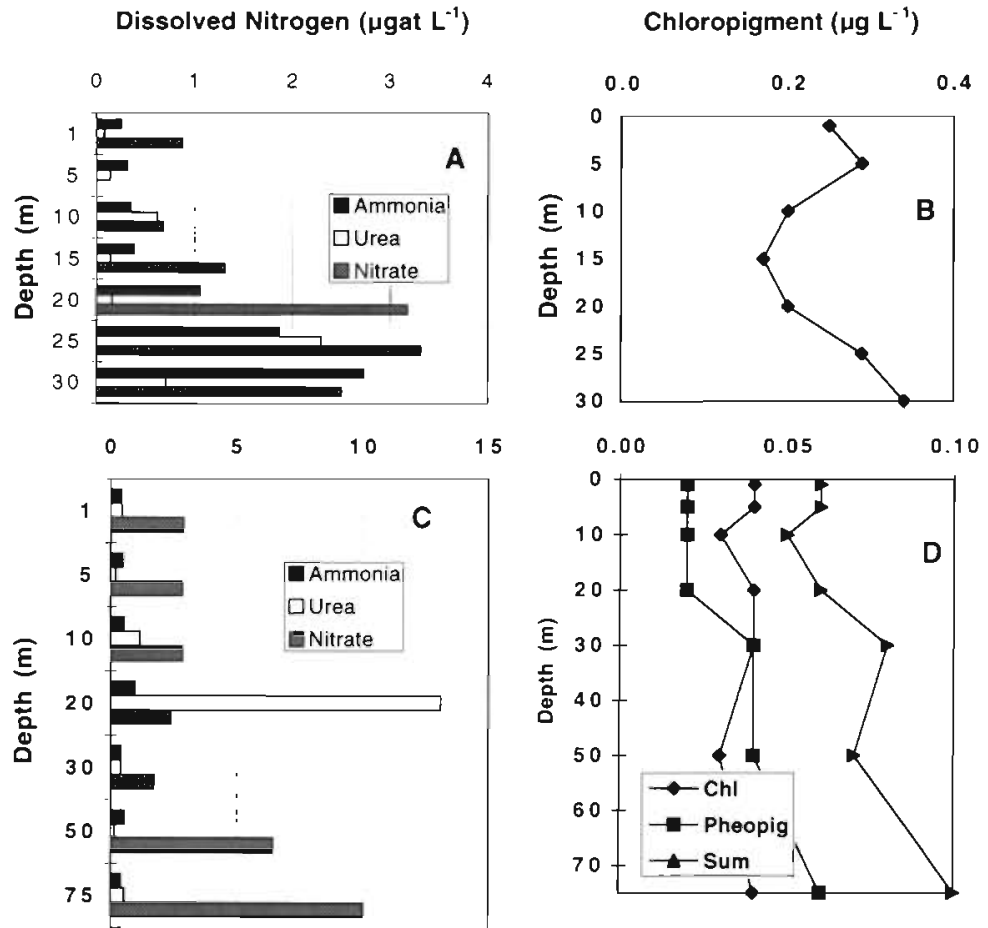

Fig. 5. Distribution of dissolved nitrogen species compared with chlorophyll-related pigments in the water column in Allen Bay after freezeup, 1993. (A, B) October 21, Resolute Bay: (C, D) November 23, Allen Bay

\section{Ice chemistry}

We did not recognize the possible significance of nitrogenous compounds in the ice at the start of POLAR PRO so only 3 dates were sampled during the 1992-1993 ice year. On January 30 relatively large concentrations of urea were noted in the bottom ice and surface samples while the concentrations of ammonia were low (Fig. 6). In mid-February, samples were cored from adjacent locations differing primarily in the amount of snow covering the ice. Neither core series showed differences that might be attributable to differences in snow cover but the overall concentrations of nitrogen were relatively low. The highest concentrations of urea were in the surface portion, and of nitrate near the ice-water interface, and with ammonia concentrations were considerably higher in mid-and deeper ice zones, in contrast with January cores, in which ammonia was much less concentrated than urea at all depths (Fig. 7A,B).

Interest in the role of urea in the ice was greatly augmented by the high concentrations found on May 25. Two large cores 
were recovered in the process of cutting a new sampling hole for use in the ice shack and then sub-sampled for ice chemistry (see 'Materials and methods'). The first of these (Fig. 8A) was smaller in diameter but yielded a large concentration of urea in the surface sample in contrast, the larger core yielded a sample of even higher concentration (Fig. 8B), but in the middle rather than at the surface.

Although an effort was made to get another core series before break-up to verify these very high concentrations, we were unsuccessful. However, we made a series of short core collections in the fall as soon as ice thickness was sufficient to support the coring operations, and compared the several ice sections with water collected from just beneath the ice at the same time as the cores were taken (see 'Materials and methods').
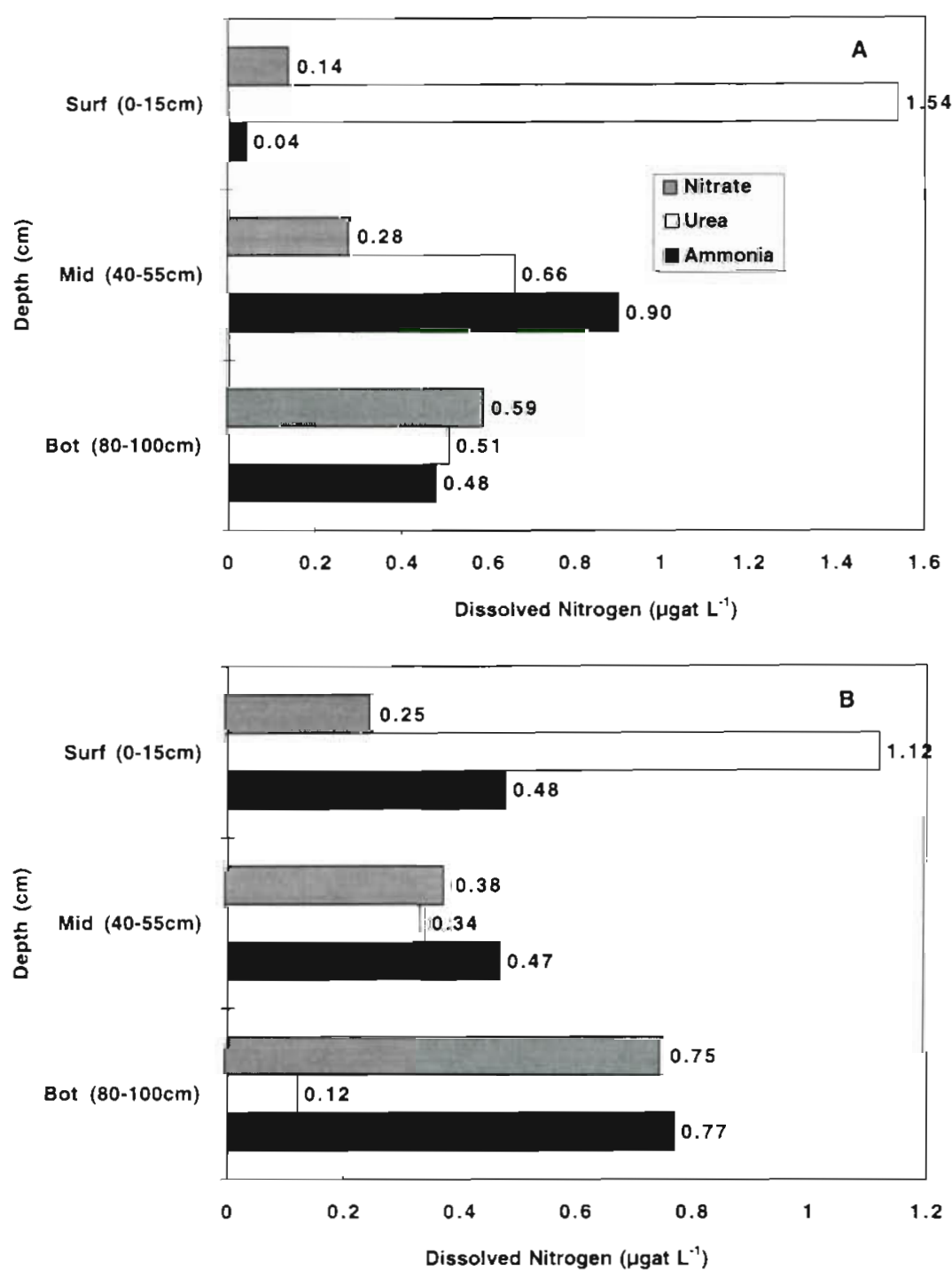

Fig. 7. Distribution of dissolved nitrogen species in sea ice near the ice camp off Sight Point, February 18, 1993, under (A) small and (B) large snow depth
Samples were collected from the ice in Resolute Bay on October 15 and October 18 which showed relatively high urea concentrations in the ice, often highest in the bottom cores; lesser amounts of ammonia, perhaps 10 to $50 \%$ of the urea present (Fig. 9A,B); and much lower concentrations of both regenerated forms of nitrogen in the sub-ice water (Fig. 9B). We moved our operations to Allen Bay on October 20, which showed considerably lower concentrations of ammonia and urea in the ice, but still lower concentrations of urea in the water beneath the ice, although the concentrations of ammonia were about the same in the ice and beneath it (Fig. 10A,B). Samples were taken again from Allen Bay on November 13; these showed little difference between ammonia concentrations of the samples in and out of the ice, but much more urea in the water (Fig. 11A). By December 4 water and bottom ice samples were similar in both ammonia and urea content, but showed more ammonia and more urea in mid-ice and near the ice surface (Fig. 11B). We also point out that over this $45 \mathrm{~d}$ interval the ice increased more than half a meter in thickness.

\section{DISCUSSION}

A major concern with both water bottle and ice samples was their considerable variability, perhaps not surprising considering that several water masses contribute to the, transport through Barrow Strait (Prinsenberg \& Bennett 1987). Despite fluctuations, the general pattern of nitrate regeneration, or renewal, during the dark season seemed to follow the typical high latitude pattern so that nitrate was present in good abundance at the start of the light season, with regenerated forms becoming increasingly important when the ice melted and primary production approached the annual maximum (Harrison \& Cota 1991).

If the above pattern was determining the production processes in Barrow Strait, one might anticipate a negative correlation between nitrate and the forms of regenerated nitrogen ammonia and urea. To test this hypothesis we compared each nitrogen species with the other 2 by means of regression statistics as shown in Table 2. In each pair involving urea 
the regressions were run with and without an outlier (November 23, 1993, $20 \mathrm{~m}$ ) mentioned in the 'Results' and shown in Fig. 5C. While not exactly a powerful test, the null hypothesis that no pair of the 3 variables would show a correlation over time cannot be rejected in 4 of 5 cases and the level of significance in the fifth case would seem to have limited predictive power although suggesting that both regenerative nutrients increase or decrease in the same way. This was the ammonia-urea series from which the urea outlier had been removed (Table 2).

Virtually the same approach was taken with the chemical information from the ice, except that so few nitrate samples had been processed that it was statistically impractical to include them. However, the simple regression between ammonia and urea, both in the ice, was highly significant (Table 3). Data from ice samples collected on May 25, 1993, contained some rather high concentrations of urea, and, although there was no obvious reason to remove any data from the set, we first removed the 2 rather high data pairs and then removed all the data for May 25, without changing the significance. Hence we might conclude that the presence of ammonia in the ice indicates the likelihood of finding proportionately more urea in the same sample. We also examined the distribution of urea in the ice using a single factor ANOVA assuming that there were no systematic differences in concentration between surface, bottom and middle portions; we could not disprove that null hypothesis.

In an attempt to clarify the possible sources of the urea in the system, we carried out 1 further statistical analysis using data gathered only from 'new' ice, i.e. that formed in the fall of 1993 in the Resolute area (Resolute Bay and Allen Bay). We compared the nutrient content of ice in the bottom cores with water collected from directly beneath the ice, and presumably in contact with it, although probably not at the exact location from which the ice came, using the non-parametric Mann-Whitney $U$-test (Siegel 1956). In the first analysis we used bottom ice from 5 dates but sub-ice water from only 4 dates. The resulting value of $U$ could be used to calculate a value for $p$ of 0.0174 . When we removed the ice data from October 15, for which no sub-ice water had been collected, p then became 0.0582 , so whether or not one rejects the hypothesis that there is no difference in nitrogen chemistry between bottom ice and proximal sea water depends on what level of probability one accepts as convincing. We carried out a similar analysis using ammonia which yielded values of $p=0.0526$ and $p=$ 0.1611 with the same treatment. The implication here would generally support the argument that urea tends
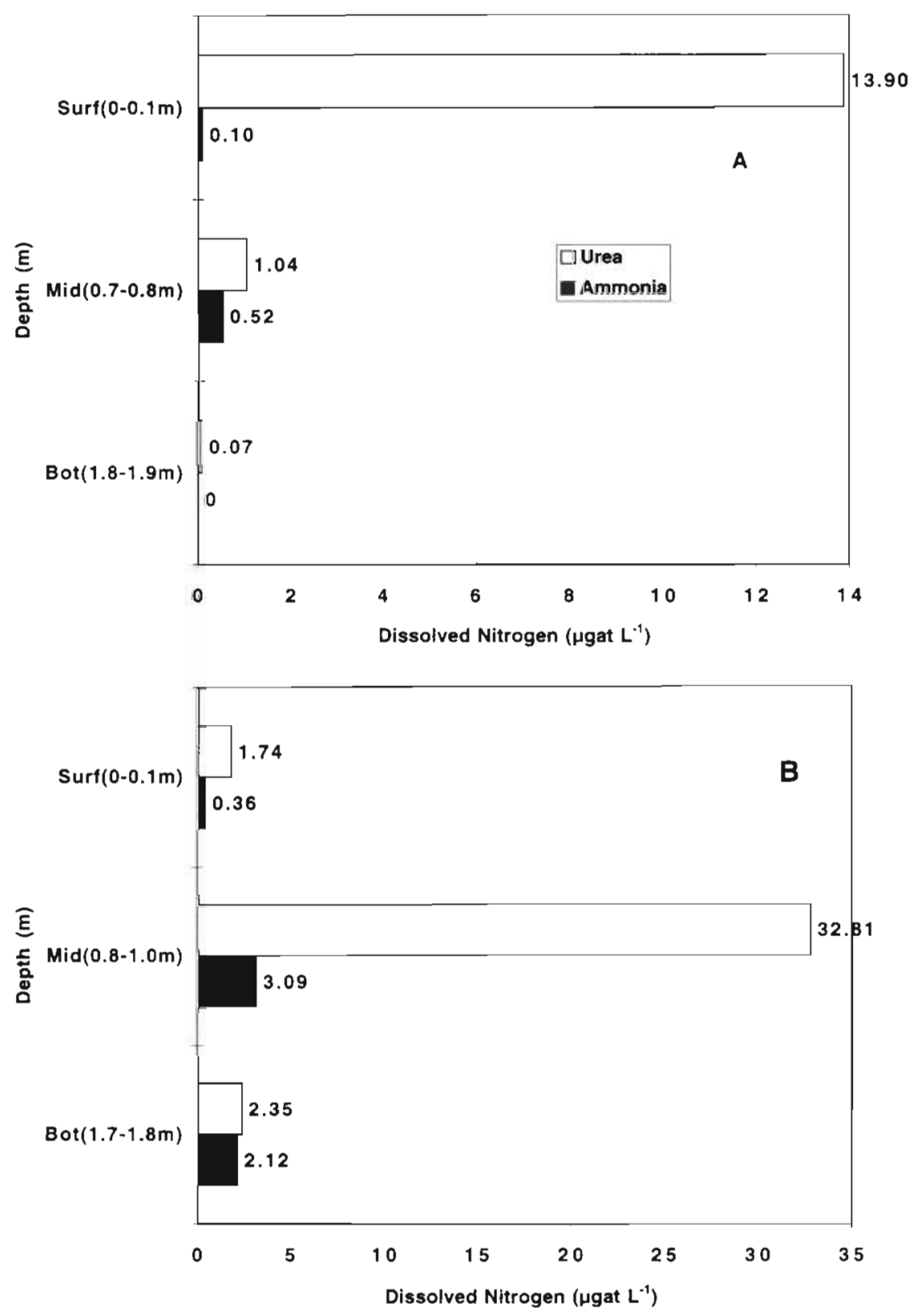

Fig. 8. Distribution of ammonia and urea in sea ice near the ice camp off Sight Point, May 25, 1993. (A, B) adjacent ice cores 

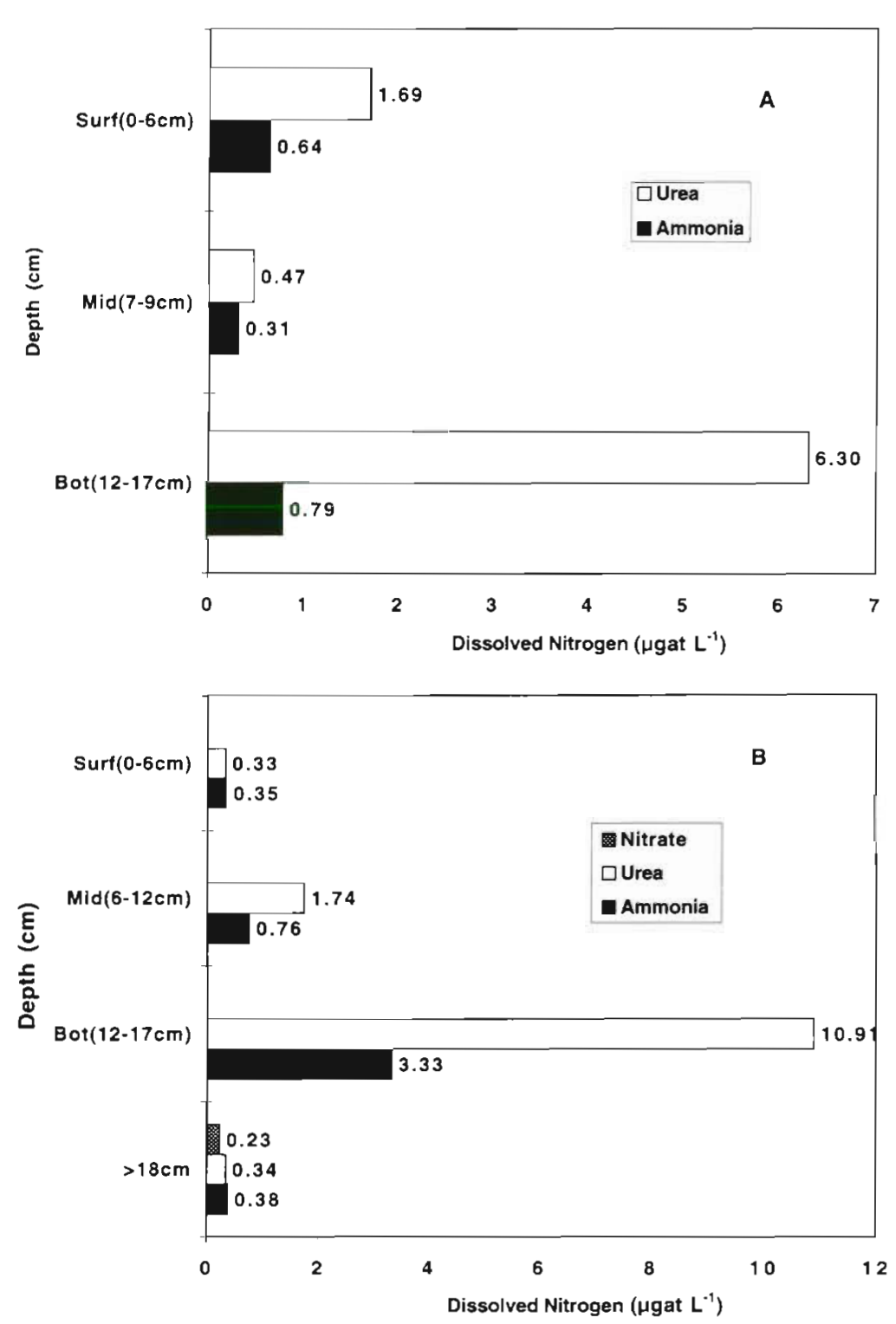

Fig. 9. Distribution of ammonia and urea in sea ice in Resolute Bay: (A) October 15, 1993; (B) October 18, 1993. In (B), all 3 dissolved species in the subice sea water on the same date are also shown

to be higher in concentration in the bottom ice than ammonia, but only slightly higher.

At this point it would seem sensible to review the physics and chemistry of the freezing processes in the sea as they are probably affecting the distribution of nutrients and salt content in a high arctic environment. Under calm conditions, with air temperature considerably below $-1.8^{\circ} \mathrm{C}$, the freezing point of average sea water, flat platelet-like crystals spread rapidly over the water surface until a continuous layer is formed, after which there is competitive growth downward to form a layer of columnar crystals. From this point downward growth becomes somewhat irregular, forming a den- dritic network of alternating ice platelets separated by packets of brine. As the ice thickens and matures, the brine packets become cut off so that the proportion of brine to ice decreases with distance from the ice-water interface (Weeks 1976). While the details of the chemistry of brine in sea ice are quite complex, for most purposes, and where the ice-brine system is developing at temperatures warmer than $-22^{\circ} \mathrm{C}$, there is a simple linear relation available to calculate brine volume as a function of temperature and salinity (Frankenstein \& Garner 1967). Hence, in newly forming ice, the highest salinities where the ice is consolidating might be 12 to $15 \%$ while, after a year's growth, during which time considerable brine will have drained from the system, the average salinity might be 4 to $5 \%$. The salinity profile will not be linear, but would have a $\mathrm{C}$-shape over the first meter of ice, with higher salt content near the surface, about $1 \%$ less in the middle of the column and with increased salt near the bottom. These profiles change further with age of the ice and degree of summer melting and re-freezing (Weeks 1976). But the point of this discussion is to emphasize that, assuming the nutrient salts behave generally as part of the brine package, their concentration in the ice should be considerably less than in the proximal sea water, not higher as we have frequently observed. Presumably biology is in some way involved with the generation of this paradox.

Regrettably there is really very little information on the distribution of nitrogen-containing compounds in sea ice. Some years ago, Parker et al. (1978a) measured nitrate and ammonia in ice cores taken from the Antarctic ice sheet which they postulated could have been fixed by auroral activity (Wilson \& House 1965) and which could have contributed between 0.02 and $7 \%$ of the average upper mixed-layer concentration of nitrate- $\mathrm{N}$ as a consequence of the seasonal melting of the ice sheet. Subsequently Biggs (1978) calculated that the ammonia in the melting ice sheet might contribute $2 \%$ of the standing stock of ammonia in the upper water, based on his ammonia data from the Ross Sea and south of the Antarctic Convergence. In response to Biggs' contribution, Parker et al. (1978b) mention finding $\mathrm{NO}_{3}-\mathrm{N}$ up to $37 \mu \mathrm{g}$-at. $\mathrm{l}^{-1}$ and $\mathrm{NH}_{4}-\mathrm{N}$ up to $19 \mu \mathrm{g}$-at. $\mathrm{l}^{-1}$ in glacial ice, 
concentrations higher than most that we found in sea ice (Table 4).

Studies of epontic communities in Canadian arctic archipelago and Frobisher Bay have emphasized the distribution primarily of nitrate, phosphate and silicate in relation to ice-algal growth, with little emphasis on recycled nitrogen (Grainger 1977). Cota et al. (1987) have examined the profiles of these 3 nutrients through roughly $1.8 \mathrm{~m}$ of sea ice, concluding that the total 'supply', were it instantly available, would approximately equal the concentration of the same nutrients in the upper $0.5 \mathrm{~m}$ of the water column. Indeed the concentration in the ice would suggest that it is the 'residual' from the desalination process, especially as there is an increase in the bottom $5 \mathrm{~cm}$, which represents the most recently formed ice (Cota et al. 1990). More recent multi-year observations from Frobisher Bay, Canada, included regular measurements of ammonia, which was routinely more highly concentrated in the bottom 5 cm of ice, in contrast with nitrate, phosphate and silicate, which were nearly always more concentrated in the sub-ice water (Hsiao 1988). Metabolic waste from the highly concentrated under-ice communities are probably responsible. Regrettably urea was not determined. Nor was the micro-distribution of urea examined by Smith et al. (1990), although they recorded sharp vertical gradients for chlorophyll, and the nutrients nitrate, nitrite, ammonia, phosphate and silicate, in the bottom few mm of ice. On the other hand, in virtually the same sea ice environment, Harrison et al. (1990) found that the bottom 'skeletal' layer of ice algae from ice auger cores took up nitrate, ammonia and urea in incubation experiments. Urea concentrations often exceeded ammonia, but the rate of uptake was about half that for ammonia. Even so urea accounted for about $22 \%$ of the total nitrogen (nitrate, ammonia and urea) utilized. Recent studies have shown that sea ice, though relatively rare in Kiel Bight, Germany, supported abundant bacteria and nutrients in brine and brackish sea ice but urea was not measured (Mock et al. 1997).

Elsewhere in northern high latitudes there are several examples of urea being relatively important in environments where seasonal ice can have considerable impact, although not necessarily at the time of the study. In Baffin Bay and Lancaster Sound, Canada, in summer, urea often accounted for $>50 \%$ of the dissolved nitrogen (Harrison et al. 1985). In the northern Bering Sea pelagic grazers and a rich benthos consume $30 \%$ and $40 \%$ of the water column production respectively and here $65 \%$ of the nutrients were regenerated, including considerable urea (Hansell \& Goering 1990). Under the ice in the Barents Sea, concentrations of ammonia and urea were low and uptake rates were generally negligible, but south of the marginal ice zone, where nitrate concentration was effectively zero, the opposite was true, and urea concentration occasionally exceeded that of ammonia (Kristiansen \& Farbrot 1991). In most of the cases where urea uptake was significant, the concentration of nitrate in the environment was considerably reduced. Also, urea concentrations, some $>1 \mu \mathrm{g}$-at. $\mathrm{N} \mathrm{l}^{-1}$, 
and uptake were generally more important in environments where the phytoplankton biomass was relatively low (Kristiansen \& Lund 1989). A more recent
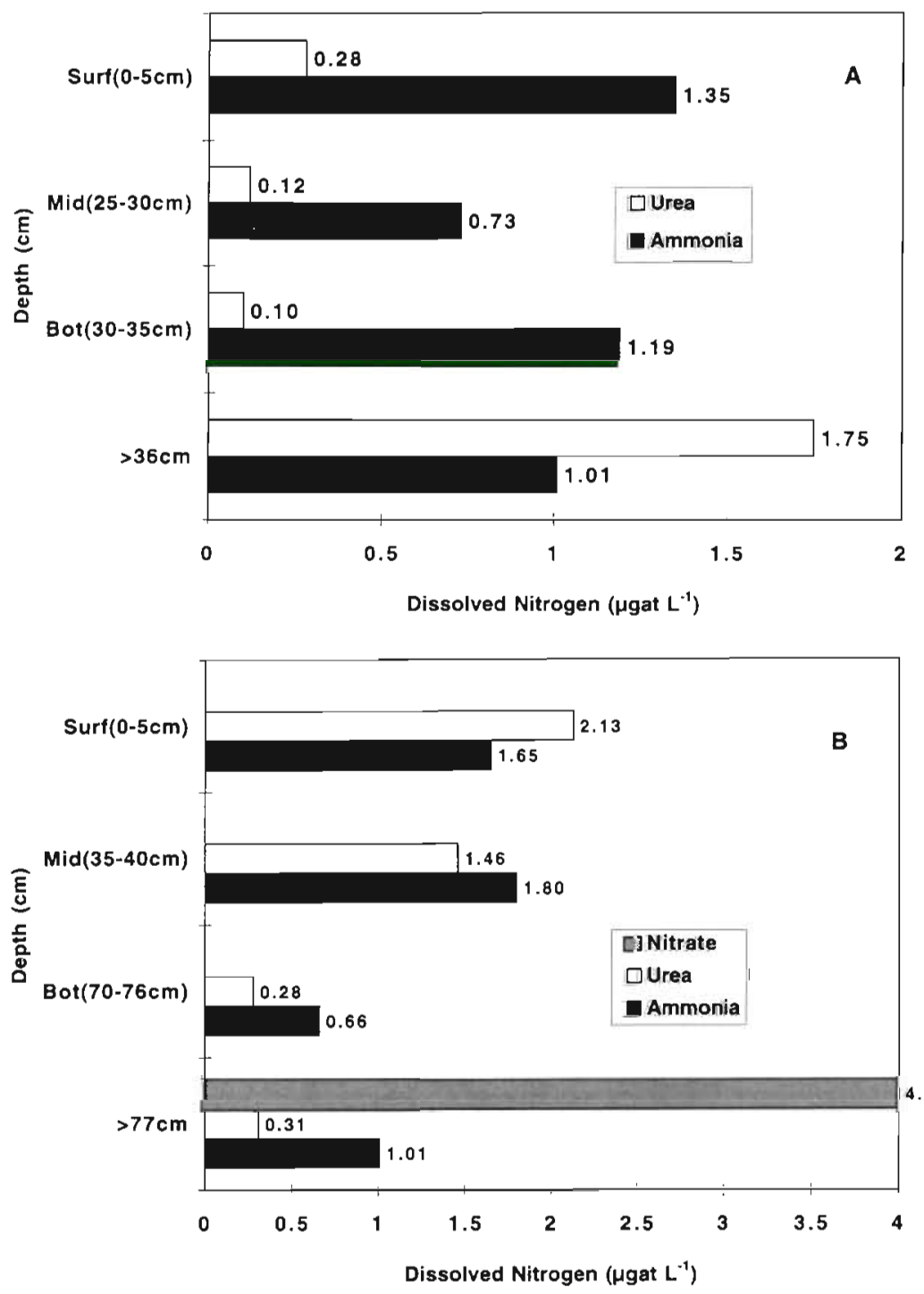

Fig. 11. Distribution of ammonia and urea in sea ice and in sub-ice sea water in Allen Bay: (A) November 13, 1993; (B) December 4, 1993. In (B), nitrate in the sub-ice sea water is also shown paper by Kristiansen et al. (1994) emphasized nitrogen dynamics in the Barents Sea on a seasonal basis, but, regrettably from our point of view, they did not partition the regenerated nitrogen in the postbloom period when the $f$-ratios were lower. Mention was made of high urea concentrations in May and June co-occurring with the presence of whales during sampling, but this would not appear to be a likely source for increasing urea concentrations in the fast ice.

In polar regions of the Southern Hemisphere nutrient relations can be rather different than in the north. For one thing maximum nitrogen concentrations are usually substantially higher in the Antarctic, although this does not appear to be the case in the ice itself (Table 4). A comparative list of differences has been prepared by Spindler (1994), pointing out that arctic ice is usually older, thicker, less saline, harder, and has less space for organisms (those present being mostly in the under-ice layer) and a greater proportion of land fast ice over shallow water than is characteristic of the Southern Ocean. Where it occurs in the Antarctic, land fast ice is characterized by a bottom platelet layer rich with algal and bacterial populations that stores considerable nutrients, but few investigators have been concerned with regenerated nutrients, particularly urea (Table 4). In contrast, the harder congelation ice in McMurdo Sound contains nutrients at a similar concentration to those found in the typical arctic fast ice environment (Arrigo et al. 1995). In the Weddell Sea at the start of the productive season, nitrate was the most important nitrogen source for both ice algae and phytoplankton with $f$-ratios for both in excess of 0.8 ; significant ammonia 'excretion' was only detectable

Table 2. Regression statistics and ANOVA for ammonia, urea and nitrate interaction in the water column

\begin{tabular}{|lcccccc|}
\hline & $\mathrm{R}^{2}$ & Observations & MS regression & MS residual & $F$ & Significance of $F$ \\
\hline Ammonia vs urea & 0.0333 & 91 & 5.8256 & 1.9003 & 3.0657 & 0.0834 \\
Ammonia vs urea & 0.0492 & $90^{\mathrm{a}}$ & 0.5998 & 0.1317 & 4.5525 & 0.0356 \\
Ammonia vs nitrate & 0.0236 & 83 & 13.0151 & 6.6439 & 1.9592 & 0.1654 \\
Urea vs nitrate & 0.0003 & 83 & 0.1607 & 6.8016 & 0.0236 & 0.8782 \\
Urea vs nitrate & 0.0058 & $82^{\mathrm{a}}$ & 3.2418 & 6.8386 & 0.4701 & 0.4949 \\
area outlier removed & & & & & & \\
\hline
\end{tabular}


Table 3. Regression statistics and ANOVA for ammonia and urea interaction in the ice

\begin{tabular}{|c|c|c|c|c|c|c|c|}
\hline & Equation & $\mathrm{R}^{2}$ & Observations & MS regression & MS residual & $F$ & Significance of $F$ \\
\hline Ammonia vs urea & $y=3.373 x-0.484$ & 0.2272 & 45 & 289.0681 & 22.8721 & 12.6384 & $p<0.001$ \\
\hline Ammonia vs urea & $y=1.396 x+0.403$ & 0.2024 & $43^{\mathrm{d}}$ & 38.9342 & 3.7411 & 10.4073 & $0.01>p>0.001$ \\
\hline Ammonia vs urea & $y=1.475 x+0.348$ & 0.1986 & $39^{b}$ & 37.5161 & 4.0926 & 9.1669 & $0.01>\hat{p}>0.001$ \\
\hline
\end{tabular}

Table 4. Distribution of common nutrients in sea and glacial ice found in various Arctic und Antarctic studies. All concentrations in $\mu$ g-at. $1^{-1}$

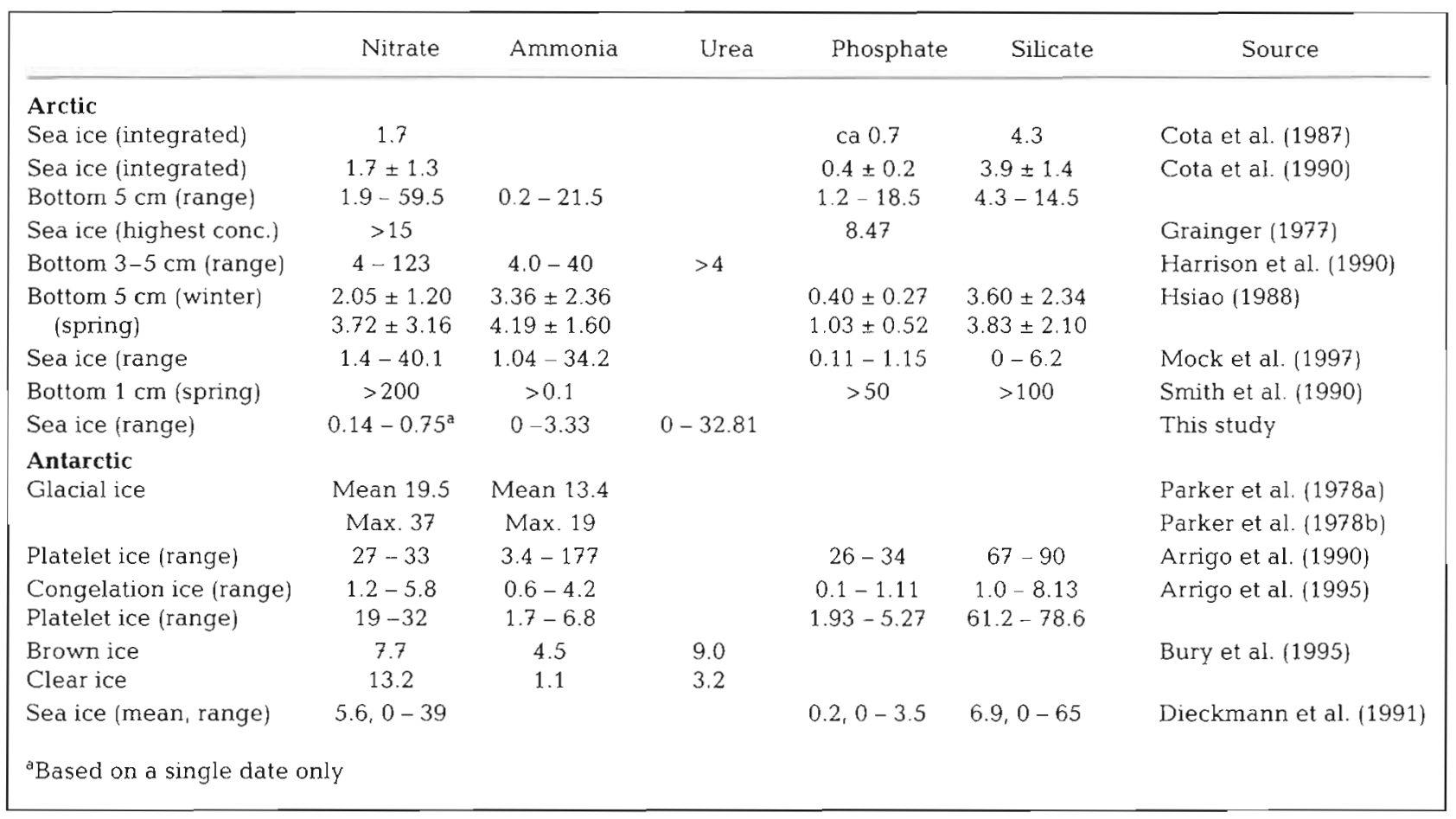

in the ice-algal community (Kristiansen et al. 1992), and apparently did not accumulate in the ice (Dieckmann et al. 1991). However, conditions were dramatically different near the marginal ice zone of the Bellingshausen Sea also in the productive season, especially in and near the ice. In 'brown ice', urea had the highest uptake rate, only slightly greater than that of nitrate, but ammonia uptake was still almost $25 \%$ of the total. In another location in the ice, ambient urea concentrations up to $2 \mathrm{mmol} \mathrm{m} \mathrm{m}^{-3}$ were observed, with uptake 6 times that of either nitrate or ammonia. Total uptake was an order of magnitude higher here than in clear ice, under the ice or in open water, although the standing stock differed by 4 times or less and indeed nitrate was more concentrated in the clear ice (Bury et al. 1995; Table 4).
The possibility certainly exists that the urea production in the ice is at least partly related to bacterial activity. A recent paper by Cho et al. (1996) found that urea production by bacteria could account for 35 to $91 \%$ of the estimated nitrogen demand by phytoplankton in the Southern California Bight, USA; such production was also 2 orders of magnitude greater than the rate of urea degradation by bacteria in the same environment. So far as we are aware, the production of urea by bacteria in ice-related environments has not been studied, but there is ample evidence that bacteria can survive and grow in or in near contact with ice (Dahlbäck et al. 1982, Smith et al. 1989, Kottmeier \& Sullivan 1990, Mordy et al.1995), but not at a sufficiently rapid rate to seriously influence our frozen nutrient samples (Grossman \& Gleitz 1993). 
How important might the urea be that is incorporated into the fast ice over the course of a 'winter'? We show the amount of urea which we encountered over 8 sampling dates in Table 5, each based on the average urea concentration and the estimated thickness of the ice at the time. Highest average concentration was on May 25, which also had an ice thickness close to the maximum attained by the first year ice off Resolute and also nearer to the typical thickness of the arctic sea ice (>2 m) given by Spindler (1994) than any of our other samples. Therefore, for the following calculation we will assume an average concentration of $16 \mathrm{mg}$-at. $\mathrm{N} \mathrm{m}^{-2}$ in the form of urea, recognizing that the evidence for universality of such a high concentration does not exist at this time. Taking a maximum ice cover of $14 \times 10^{6} \mathrm{~km}^{2}$ in the arctic from Table 1 in Spindler (1994), equivalent to $14 \times 10^{12} \mathrm{~m}^{2}$, and $16 \mathrm{mg}$-at. $\mathrm{N} \times 14=224 \mathrm{mg} \mathrm{N} \mathrm{m}^{-2}$, we calculate that $14 \times 0.224 \times 10^{12}=3.136 \times 10^{12} \mathrm{~g} \mathrm{~N}$ or $3.136 \times 10^{6}$ metric tonnes could potentially be incorporated into the arctic ice by the end of winter. Half of this would presumably contribute to the next years' nutrient enrichment, but the other half could accumulate in the multi-year ice where it might be interpreted as evidence for earlier sympagic community production. Consider also that this ice could contain $1.344 \times 10^{6}$ tonnes of carbon, since urea is an organic compound. Still in the realm of conjecture and using the same data source (Spindler 1994), assuming that urea accumulates there in the same proportions, then $4.48 \times 10^{6}$ tonnes of nitrogen and $1.92 \times 10^{6}$ tonnes of carbon might be found in Southern Ocean seasonal ice at its peak, although $80 \%$ of this could be dissipated during the summer melt. So possibly polar sea ice might store information about earlier production cycles, even if only temporarily. It will not be easy to verify this hypothesis in the short run but a more detailed study of the chemistry of sea ice, and especially multi-year sea ice, would seem to be desirable.

Table 5. Urea in the ice column in th Resolute area, 1993

\begin{tabular}{|lccc|}
\hline Date & $\begin{array}{c}\text { Average urea } \\
\text { concentration in the } \\
\text { ice }\left(\mathrm{mg}^{2} \text {-at. } \mathrm{N} \mathrm{m}^{-3}\right)\end{array}$ & $\begin{array}{c}\text { Ice thick- } \\
\text { ness } \\
(\mathrm{m})\end{array}$ & $\begin{array}{c}\text { Urea in } \\
\text { the ice } \\
\left.\text { (mg-at. } \mathrm{N} \mathrm{m}^{-2}\right)\end{array}$ \\
\hline 30 Jan 93 & 3.85 & 1.00 & 3.850 \\
18 Feb 93 & 0.72 & 1.20 & 0.864 \\
25 May 93. & 8.65 & 1.85 & 16.002 \\
15 Oct 93 & 2.65 & 0.17 & 0.450 \\
18 Oct 93 & 3.19 & 0.17 & 0.542 \\
20 Oct 93 & 0.93 & 0.14 & 0.130 \\
13 Nov 93 & 0.16 & 0.35 & 0.056 \\
4 Dec 93 & 1.29 & 0.76 & 0.980 \\
\hline
\end{tabular}

Acknowledgements. We are very grateful to Buster Welch, whose dedication and persistence in the face of considerable financial adversity enabled the completion of POLAR PRO, and to Cathy Welch, who managed the critical logistical problem of keeping us all well fed over a full polar year. Peter Amerualik, Henry Landry and Tim Siferd were critical members of the scientific team in the field and Tim Siferd and Kathy Martin made important logistical contributions during the preparations of this paper. We dedicate this paper to the memory of our colleague Nicolai Mumm, whose untimely death on 7 April 1997 shocked and saddened us all.

\section{LITERATURE CITED}

Arrigo K, Dieckmann G, Gosselin M, Sullivan C (1990) Studies on the nutrient status in sea ice and underlying platelet layer of McMurdo Sound. Antarct J US 25:185-188

Arrigo KR, Dieckmann G, Gosselin M, Robinson DH, Fritsen $\mathrm{CH}$, Sullivan CW (1995) High resolution study of the platelet ice ecosystem in McMurdo Sound, Antarctica: biomass, nutrient, and production profiles within a dense microalgal bloom. Mar Ecol Prog Ser 127:255-268

Bedo AW. Head EJH, Conover RJ, Horne EPW, Harris LR (1990) Physiological adaptations of an under-ice population of Pseudocalanus in Barrow Strait (N.W.T.) to increasing food supply in spring. Polar Biol 10:561-570

Bergmann MA, Welch HE, Butler-Walker JE, Siferd TD (1991) Ice algal photosynthesis at Resolute and Saqvaqjuac in the Canadian arctic. J Mar Syst 2:43-52

Biggs DC (1978) Non-biogenic fixed nitrogen in antarctic surface waters. Nature 276:96-97

Bury SJ, Owens NJP, Preston T $(1995){ }^{13} \mathrm{C}$ and ${ }^{15} \mathrm{~N}$ uptake by phytoplankton in the marginal ice zone of the Bellingshausen Sea. Deep-Sea Res II 42:1225-1252

Cho BC. Park MG, Shim JH, Azam F (1996) Significance of bacteria in urea dynamics in coastal surface waters. Mar Ecol Prog Ser 142:19-26

Conover RJ, Gustavson KR (1999) Sources of urea in arctic seas: zooplankton metabolism. Mar Ecol Prog Ser 179:41-54

Cota GF, Horne EPW (1989) Physical control of arctic ice algal production. Mar Ecol Prog Ser 52:111-121

Cota GF. Prinsenberg SJ, Bennett EB, Loder JW, Lewis MR, Anning JL, Watson NHF, Harris LR (1987) Nutrient fluxes during extended blooms of arctic ice algae. J Geophys Res 92(C2):1951-1962

Cota GF, Anning JL, Harris LR, Harrison WG, Smith REH (1990) Impact of ice algae on inorganic nutrients in seawater and sea ice in Barrow Strait, NWT, Canada, during spring. Can J Fish Aquat Sci 47:1402-1415

Dahlbäck B, Gunnarsson LÂH, Hermansson M, Kjelleberg S (1982) Microbial investigations of surface microlayers, water column, ice and sediment in the Arctic Ocean. Mar Ecol Prog Ser 9:101-109

Dieckmann GS, Lange MA, Ackley SF, Jennings JC Jr (1991) The nutrient status in sea ice of the Weddell Sea during winter: effects of sea ice texture and algae. Polar Biol 11: $449-456$

Dugdale RC, Goering JJ (1967) Uptake of new and regenerated forms of nitrogen in primary productivity. Limnol Oceanogr 12:196-206

Frankenstein G, Garner R (1967) Equations for determining the brine volume of sea ice from $-0.5^{\circ} \mathrm{C}$ to $-22.9^{\circ} \mathrm{C}$. J Glaciol 6:943-944

Grainger EH (1977) The annual nutrient cycle in sea-ice. In: Dunbar MJ (ed) Polar oceans. Arctic Institute of North America, Calgary, p 225-300 
Grossman S, Gleitz M (1993) Microbial responses to experimental sea-ice formation: implications for the establishment of Antarctic sea-ice communities. J Exp Mar Biol Ecol 173:273-289

Hansell DA, Goering JJ (1990) Pelagic nitrogen flux in the northern Bering Sea. Cont Shelf Res 10:501-519

Harrison WG, Cota GF (1991) Primary production in polar waters: relation to mutrient availability. In: Sakshaug $E_{\text {, }}$ Hopkins CCE, Øritsland NA (eds) Proc Pro Mare Symp Polar Mar Ecol, Trondhejm, 12-16 May 1990. Polar Res 10(1):87-104

Harrison WG, Platt T (1986) Photosynthesis-irradiance relationships in polar and temperate phytoplankton populations. Polar Biol 5:153-164

Harrison WP, Head EJH, Conover RJ, Longhurst AR, Sameoto DD (1985) The distribution and metabolism of urea in the eastern Canadian Arctic. Deep-Sea Res 32:23-42

Harrison WG, Cota GF, Smith REH (1990) Nitrogen utilization in ice algal communities of Barrow Strait, Northwest Territories, Canada. Mar Ecol Prog Ser 67:275-283

Hsiao SIC (1988) Spatial and seasonal variations in primary production of sea ice microalgae and phytoplankton in Frobisher Bay, Arctic Canada. Mar Ecol Prog Ser 44:275-285

Kottmeier ST, Sullivan CW (1990) Bacterial biomass and production in pack ice of antarctic marginal ice edge zones Deep-Sea Res 37:1311-1330

Kristiansen S, Farbrot T (1991) Nitrogen uptake rates in phytoplankton and ice algae in the Barents Sea. In: Sakshaug E, Hopkins CCE, Øritsland NA (eds) Proc Pro Mare Symp Polar Mar Ecol, Trondheim, Norway, 12-16 May 1990. Polar Res 10(1):187-192

Kristiansen S, Lund BAa (1989) Nitrogen cycling in the Barents Sea-I. Uptake of nitrogen in the water column. Deep-Sea Res 36:255-268

Kristiansen S, Syvertsen EE, Farbrot T (1992) Nitrogen uptake in the Weddell Sea during late winter and spring. Polar Biol 12:245-251

Kristiansen S, Farbrot T, Wheeler PA (1994) Nitrogen cycling in the Barents Sea - seasonal dynamics of new and regenerated production in the marginal ice zone. Limnol Oceanogr 39:1630-1642

Legendre L, Ackley SF, Dieckmann GS, Gulliksen B, Horner R, Hoshiai T, Melnikov IA, Reeburgh WS, Spindler M, Sullivan CW (1992) Ecology of sea ice biota 2. Global significance. Polar Biol 12:429-444

Maykut GA (1985) The ice environment. In: Horner RA (ed) Sea ice biota. CRC Press, Boca Raton, FL, p 21-82

McCarthy JJ (1970) A urease method for urea in sea water Limnol Oceanogr 15:309-313

Mock T, Meiners KM, Giesenhagen HC (1997) Bacteria in sea ice and underlying brackish water at $54^{\circ} 26^{\prime} 5^{\prime} \mathrm{N}$ (Baltic, Kiel Bight). Mar Ecol Prog Ser 158:23-40

Mordy CW, Penny DM, Sullivan CW (1995) Spatial distribution of bacterioplankton biomass and production in the

Editorial responsibility: Otto Kinne (Editor),

Oldendorf/Luhe, Germany marginal ice-edge zone of the Weddell-Scotia Sea during austral winter. Mar Ecol Prog Ser 122:9-19

Parker BC, Heiskell LE, Thompson WJ, Zeller EJ (1978a) Non-biogenic fixed nitrogen in Antarctica and some ecological implications. Nature 271:651-652

Parker BC, Heiskell LE. Thompson WJ, Zeller EJ (1978b) Non-biogenic fixed nitrogen in Antarctic surface waters - reply. Nature 276:297

Paul JH, Carlson DJ (1984) Genetic material in the marine environment: implication for bacterial DNA. Limnol Oceanogr 29:1091-1097

Prinsenberg SJ, Bennett EB (1987) Mixing and transports in Barrow Strait, the central part of the Northwest Passage. Cont Shelf Res 7:913-935

Rey F, Skjoldal HR (1987) Consumption of silicic acid below the euphotic zone by sedimenting diatom blooms in the Barents Sea. Mar Ecol Prog Ser 36:307-312

Siegel S (1956) Nonparametric statistics for the behavioral sciences. McGraw-Hill, New York

Smith REH, Anning J, Clement P, Cota G (1988) Abundance and production of ice algae in Resolute Passage, Canadian Arctic. Mar Ecol Prog Ser 48:251-263

Smith REH, Clement P, Cota GF (1989) Population dynamics of bacteria in arctic sea ice. Microb Ecol 17:63-76

Smith REH, Harrison WG, Harris LR, Herman AW (1990) Vertical fine structure of particulate matter and nutrients in sea ice of the high arctic. Can J Fish Aquat Sci 47: $1348-1355$

Solórzano 1 (1969) Determination of ammonia in natural waters by the phenolhypochlorite method. Limnol Oceanogr 14:799-801

Spindler M (1994) Notes on the biology of sea ice in the Arctic and Antarctic. Polar Biol 14:319-324

Stainton MP, Capel MJ, Armstrong FAJ (1977) The chemical analysis of fresh water, 2nd edn. Can Fish Mar Serv Misc Spec Publ 25

Stefansson U, Olafsson J (1990) Anomalous silicate-nitrate relationships associated with Phaeocystis pouchetii blooms. EOS 71:66

Weeks WF (1976) Sea conditions in the arctic. Arctic Ice Dynamics Joint Experiment (AIDJEX) Bull 34:173-206

Welch HE, Bergmann MA, Jorgenson JK, Burton W (1988) A subice suction corer for sampling epontic ice algae. Can $J$ Fish Aquat Sci 45:562-568

Welch HE, Siferd TD, Bruecker P (1997) Marine zooplanktonic and benthic community respiration rates at Resolute, Canadian high Arctic. Can J Fish Aquat Sci 54: 999-1005

Wilson AT, House DA (1965) Fixation of nitrogen by aurora and its contribution to the nitrogen balance of the earth. Nature 205:793-794

Yentsch CS, Menzel DW (1963) A method for the determination of phytoplankton chlorophyll and phaeophytin by fluorescence. Deep-Sea Res 10:221-231

Submitted: November 28, 1997; Accepted: November 18, 1998 Proofs received from author(s): March 31, 1999 